\title{
Analysis on the Relationship between Financing Constraints and Research and Development from the Perspective of the Location of Top Management Network
}

\author{
Jinzhong Li 1 ) \\ School of Accountancy, Shandong University of Finance and Economics, Jinan 250014, China \\ Correspondence should be addressed to Jinzhong Li; 20058848@sdufe.edu.cn
}

Received 12 November 2021; Revised 14 December 2021; Accepted 21 December 2021; Published 6 January 2022

Academic Editor: Daqing Gong

Copyright ( $) 2022$ Jinzhong Li. This is an open access article distributed under the Creative Commons Attribution License, which permits unrestricted use, distribution, and reproduction in any medium, provided the original work is properly cited.

\begin{abstract}
Taking listed Chinese companies during 2009-2019 as objects, this paper constructs a multivariate discriminant model to measure the degrees of multiple financing constraints and establishes empirical models to analyze the non-linear relationship between the financing constraints and research and development (R\&D) investment. Further, the author investigated how the top management network (TMN) location acts on the relationship between financing constraints and R\&D investment. The research provides a robust evidence to an inverted $U$-shaped relationship between the degrees of financing constraints and corporate $R \& D$ investment: appropriate financing constraints promote corporate R\&D investment; once passing a turning point, excess financing constraints would suppress corporate R\&D investment. Besides, it was learned that TMN location positively moderates the financing constraints and R\&D investment. In addition, TMN location plays a more obvious regulating role in non-state-owned enterprises (non-SOEs) than in SOEs. The research clarifies the relationship between financing constraints and R\&D investment, as well as the moderating role of TMN location. Empirical evidence was provided to help the government reduce credit discrimination and enterprises to widen financing channels and improve innovation capability.
\end{abstract}

\section{Introduction}

Innovation, a core driver of business development [1], needs financial support. However, many Chinese enterprises face financing constraints on research and development (R\&D) investment due to the immature market structure and credit discrimination [2]. Currently, there are two contradictory theories on the impact of financing constraints on innovation. On the one hand, the inhibition theory, which stems from the theory of resource dependence, holds that financing constraints reduce free cash flow and in turn suppress the innovation input of enterprises $[3,4]$. On the other hand, the promotion theory, which is based on the agency theory, argues that the lack of cash flow inhibits the moral hazard and adverse selection of the management, forcing the latter to screen high-value R\&D projects. Therefore, financing constraints could enhance corporate innovation.
Most scholars believed that financing constraints are linearly correlated with corporate innovation. Some proposed a non-linear relationship between the two. Liu et al. [5] found that high financing constraints are positively related to $\mathrm{R} \& \mathrm{D}$, while low financing constraints are negatively correlated with R\&D; the positivity/negativity of the relationship depends on the degree of financing constraints. Sun et al. [6] discovered an inverted U-shaped relationship between financing constraints and innovation performance. However, there is little report on the possibility of the nonlinearity between financing constraints and innovation.

In the literature, government policy and cash flow are the main moderators of the relationship between financing constraints and R\&D. Some policies such as digital finance, government grants, and interest rate liberalization can eventually promote the quantity and the quality of innovation level of enterprises by releasing the constraint of financing. This relationship is inevitably influenced by 
management decisions. But few scholars have explored the dynamic regulating role of the management in the relationship between financing constraints and R\&D. The Chinese society is built upon personal relationships. The top management network (TMN) formed by the social relationship of the top management could provide resources for corporate innovation. It is easy for the top managers at the core of the social relationship network to acquire innovation resources and thus substitute or alleviate the impact of financing constraints on corporate innovation. To fully clarify the effect of financing constraints on corporate innovation, it is important to explore the relationship between the two from the perspective of TMN location.

This paper intends to explore the impact of financing constraints on the $\mathrm{R} \& \mathrm{D}$ investment of listed enterprises in China and verify whether TMN location regulates the relationship between financing constraints and $R \& D$ investment. The innovations of this research are as follows:

(1) There is no consensus on the relationship between financing constraints and R\&D. Some studies consider that financing constraints promote R\&D; other studies consider that financing constraints suppress R\&D. Most studies consider the linear relationship between financing constraints and $\mathrm{R} \& \mathrm{D}$ investment. By contrast, this paper assumes that financing constraints have a non-linear impact on $\mathrm{R} \& \mathrm{D}$ investment.

(2) This paper demonstrates that appropriate financing constraints can encourage $\mathrm{R} \& \mathrm{D}$ investment. When the financing constraints reach a certain level, corporate innovation will be inhibited by the shortage of $\mathrm{R} \& \mathrm{D}$ funds. Thus, there is an inverted U-shaped relationship between financing constraints and R\&D investment.

(3) Few scholars have tackled the regulating effect of TMN location on the relationship between financing constraints and $\mathrm{R} \& \mathrm{D}$ investment. This paper puts forward the hypothesis that TMN location enhances the influence of financing constraints over R\&D investment. In order to test the non-linear moderating effect of TMN location on the relationship between financing constraints and R\&D investment, this study employs the hierarchical regression and discovers that TMN location enhances the influence of financing constraints over R\&D investment.

(4) This study further researches the heterogeneity effect of TMN location by dividing the sample into two subsamples: non-SOE sample and SOE sample. Heterogeneity analysis shows that the regulating effect of TMN location is stronger on non-stateowned enterprises (non-SOEs) than SOEs.

In summary, this study reveals the moderating mechanism of TMN location on the relationship between financing constraints and firms' R\&D investment. First, this study provides a more comprehensive understanding of the relationship between financing constraints and firms' $R \& D$ investment. Second, this study discusses attributes and values of TMN location and considers the effect of social networks and institutions on financing constraints and R\&D investment. Third, this study makes both theoretical and practical suggestions for sustainable innovation management to firms.

The remainder of this paper is organized as follows. Section 2 reviews the relevant literature and theoretically analyzes the relationship among TMN location, financing constraints, and R\&D investment. Section 3 describes the methodology and samples. Section 4 presents the empirical study and discusses the empirical results. Section 5 gives additional analysis on the influence of ownership. Section 6 summarizes the main findings and research implications.

\section{Literature Review and Theoretical Analysis}

\subsection{Financing Constraints and R\&D Investment.} Financing constraints refer to the external financing costs and difficulties (in terms of bank loans, stock/bone issuance, and so on) of an enterprise, which make the internal cash flow fall short of the capital demand for corporate development [7]. Financing constraints directly bear on corporate innovation [8].

Some scholars suggested that proper financing constraints promote enterprises to invest more in innovation. According to principal-agent theory, the managers might commit short-sighted behaviors, given an abundant cash flow. Enterprises with a high cash flow tend to make inefficient investment decisions than those with a low cash flow [9]. If financing constraints are appropriate, the managers will make fewer inefficient investments but invest more pertinently in innovation projects.

From the perspective of signal transmission, the good development of an enterprise sends the market a signal that the managers are capable, and the managers' reputation will improve. In the face of financing constraints, the managers, in order to protect their reputation, will make efficient corporate investment, stop investing in blind expansion of production capacity, and increase the efficiency of R\&D and innovation [10].

From the perspective of prospect theory, loss or failure increases the risk tolerance of individual decision makers, while success increases their risk aversion [11]. When corporate performance declines, an enterprise will take more risky innovation behaviors [12]. When the enterprise is under financing constraints, the managers will commit fewer short-sighted behaviors, due to the shortage of cash flow. For the sake of reputation, the managers tend to invest in innovative projects, which have certain risks but a high investment efficiency.

$\mathrm{R} \& \mathrm{D}$ investment, the core of corporate innovation, is easily restricted by financing constraints $[13,14]$. Innovation requires a continuous and stable investment of sufficient funds. The aggravation of financing constraints will force enterprises to curtail capital investment and halt $R \& D$ activity investment $[15,16]$, exerting a negative impact on corporate innovation $[14,17]$. According to the theory of resource dependence, an enterprise facing severe internal and external fund shortages is more inclined to invest in 
short-term quick-return projects, rather than risky and costly R\&D programs [18].

From the angle of information asymmetry, China's capital market does not have a mature mechanism. The current laws cannot effectively protect intellectual property rights [19]. If financing constraints are serious, Chinese enterprises would hold a wait-and-see attitude towards R\&D investment [20]. Since corporate R\&D is closely related to the strategic direction of the enterprise, the managers may be reluctant to disclose the key information to the investors. The resulting information asymmetry increases the cost of external financing [21]. In addition, the long cycle and high uncertainty of corporate R\&D bring the risk of an investment waterloo, which scares away investors $[17,22]$.

In the business activities of an enterprise, financing constraints could play positive and negative roles at the same time. When the financing constraints are weak, the managers can offset their negative effect by improving investment efficiency. However, the enterprise will have difficulty in resource acquisition if the financing constraints are strong. In this case, the improvement of investment efficiency cannot effectively boost corporate innovation. Therefore, inhibition will be the dominant effect of financing constraints on corporate innovation. To sum up, financing constraints in different degrees have different impacts on corporate innovation. Moderate financing constraints could drive corporate innovation, but excess financing constraints will only hinder corporate innovation. On this basis, the following hypothesis was put forward.

Hypothesis 1. As financing constraints get worse, there is an inverted U-shaped relationship between financing constraints and R\&D investment.

2.2. Moderating Effect of TMN Location. The TMN refers to the collection of direct or indirect relationships possessed by the senior management, including directors, supervisors, and executives that hold concurrent positions in other listed enterprises [23]. TMN location reflects the importance of the position occupied by a manager in the network [24]. The distance from TMN location to the structural hole $(\mathrm{SH})$ demonstrates the quality of the TMN location. The closer the distance, the better the quality of the TMN location. That is, the managers close to the $\mathrm{SH}$ can easily obtain high-quality resources, manipulate a strong network power [25], and acquire private benefits.

China has a relationship-based society, where relational transactions abound [26]. For Chinese enterprises, it is a must to establish relationship networks with the outside to obtain information and knowledge, which are the key to innovation efficiency and core competitiveness [27].

According to the theory of resource dependence, the TMN contains all the resources needed for corporate innovation, and enterprises can dig out the information embedded in the network. The ability to access critical resources depends on the TMN location [28]. If the management is close to the $\mathrm{SH}$, it will be easy for the enterprise to exchange and share social capital like knowledge, information, and technology and to gain advantages in information and innovation [29]. A resource-rich TMN enables the management to master core technologies, learn market demands, and make efficient R\&D investment [30]. These valuable resources help to reduce the risk of innovation and boost the confidence of the management, allowing them to make quick and innovative decisions. As long as financing constraints are appropriate, an enterprise can make full use of the TMN resources to implement its development strategy and business creativity. In this aspect, the TMN enhances the promoting effect of financing constraints on corporate innovation.

From the perspective of principal-agent theory, high financing constraints bring a high innovation risk. The riskaverse management may lock heterogeneous information within its interest group for private gains [31]. Moreover, when the enterprise lacks internal and external funds, the management with a limited rationality will strive to obtain funds from within the TMN and pay little attention to innovation investment.

To sum up, the TMN location determines the capital, technology, and other resources that are available to the enterprise. When the financing constraints are small, the management can acquire technical resources from the TMN to offset the negative impact of the financing constraints and improve the efficiency of innovation investment. As the financing constraints grow, the management will focus their limited energy on fundraising from within the TMN, paying less attention to the efficiency of innovation investment. Besides, a high innovation risk will make the management pursue private benefits with their TMN location. Therefore, the TMN location enhances the promoting effect of financing constraints on innovation, when financial constraints are small, and strengthens the inhibiting effect of financing constraints on innovation, when financial constraints are in excess. On this basis, the following hypothesis was put forward.

Hypothesis 2. TMN location significantly enhances the inverted U-shaped relationship between financing constraints and R\&D investment.

\section{Methodology}

3.1. Sample and Data. The research data were all collected from China Stock Market \& Accounting Research (CSMAR) Database and Wind Database. All A-share listed enterprises in Shenzhen and Shanghai stock exchanges during 2013-2019 were taken into consideration.

The SH index was calculated and processed by Pajek, a special software program of social network analysis. The index was calculated in the following steps. First, the personal features of top managers of the listed enterprises during 2013-2019 were downloaded from CSMAR. Since each top manager has a unique code, $\mathrm{R}$, a programming language, was used to transform the part-time relationship of top managers in different listed enterprises from a 2modular matrix of manager-enterprise to a 1-modular matrix of manager-manager. Then, the 1-modular matrix 
was processed and imported to Pajek, which computes the annual SH index of each senior manager and each enterprise in turn. The sum of the SHs in the TMN was taken to position the holes in corporate structure, and the mean was subjected to robustness tests.

The data of corporate innovation come from Wind Database. The data of financing constraints and control variables were obtained from CSMAR Database. The following samples were removed before analysis. (1) Listed financial and insurance enterprises were excluded, due to the unique business structure of finance. (2) Special treatment (ST) enterprises, i.e., the enterprises that received delisting warning or special treatment by Chinese Securities Regulatory Commission (CSRC) for consecutive years of losses, were eliminated, for their financial data are not comparable. (3) The enterprises with incomplete financial data were also removed. Finally, all the continuous variables were winsorized at the 1st and 99th percentiles to reduce the effect of outliers. In this way, the author obtained a sample set of 5,773 enterprise-year observations.

\subsection{Variables and Research Model}

3.2.1. Dependent Variable. The dependent variable of this research is $\mathrm{R} \& \mathrm{D}$ investment (RD). So far, corporate $\mathrm{RD}$ has been measured by various methods. In this paper, corporate $\mathrm{RD}$ was characterized by the ratio of $\mathrm{R} \& \mathrm{D}$ expenditure to total assets at the end of the year [32].

3.2.2. Independent Variable. Financing constraint (FC) is the independent variable of this research. The FC index was constructed by the binary regression model [33] in the following steps.

First, the pregrouping indices were selected. In essence, FC means the cash flow generated by business and financing activities falling short of the demand of investment activities. Therefore, sample pregrouping was carried out based on the total cash flow of operating activities and financing activities, divided by the cash flow of investment activities (hereinafter referred to as the cash flow ratio).

Second, pregrouping was carried out. The samples were ranked in ascending order by year, based on the cash flow ratio. In order to increase the contrast of the grouped samples, this paper chose the first 33\% and the last $33 \%$ as two groups. The first $33 \%$ of the observations were regarded as the high $\mathrm{FC}$ group (QUFC =1), and the last 33\% were regarded as the low FC group $(\mathrm{QUFC}=0)$.

Pregrouping was followed by binary regression. The firm's scale, debt, income, dividend payment, and liquidity are the important factors that affect the cash flow of the enterprise. The logit regression model was established based on return on assets (ROA), asset-liability ratio (Lev), log of total assets (Size), cash dividend payout ratio (CASHDIV), and liquidity ratio (LD): $Z_{i}=\alpha_{0}+\alpha_{1} \mathrm{SIZE}_{i}+\alpha_{2}$ $\mathrm{LEV}_{i}+\alpha_{3} \mathrm{CASHDIV}_{i}+\alpha_{4} \mathrm{LD}_{i}+\alpha_{5} \mathrm{ROA}_{i}$.

Based on the results of logit regression, the $\mathrm{FC}$ index was constructed as follows: $\mathrm{P}\left(\mathrm{QUFC}=1 \mid Z_{i}\right)=e^{Z i} /\left(1+e^{Z i}\right)$. The $\mathrm{P}\left(\mathrm{QUFC}=1 \mid Z_{i}\right)$ value of each enterprise in the current year was fitted as the proxy variable FC, and the value range of FC was $0-1$. The closer it is to 1 , the higher the FC of the enterprise is.

3.2.3. Moderator Variable. $\mathrm{SH}$ is the moderator variable in this research. This paper selects the limit system index to position the SH of each node in the TMN [34-36]. Firstly, the $\mathrm{SH}$ of each top manager was calculated by

$$
\operatorname{Structure}(i)=1-\left(p_{i j}-\sum_{j} p_{i q} p_{q j}\right)^{2} \text {. }
$$

Next, the SH was computed on the corporate level. After that, the SHs of top managers in each enterprise were added up and averaged:

$$
\mathrm{SH}(g)=\frac{\sum_{g}\left[1-\left(p_{i j}+\sum_{j} p_{i q} p_{q j}\right)^{2}\right]}{n}
$$

where $p_{i j}$ is the strength of the connection between enterprise $i$ and enterprise $j$ and $\sum_{j} p_{i q} p_{q j}$ is the sum of indirect connection strength between enterprise $i$ and enterprise $j$ via enterprise $q$.

3.2.4. Control Variables. Since RD could be affected by corporate features, this paper controls the following variables: financial leverage (Lev), size (Size), cash holding level (Cash), and age (Age). Furthermore, several other control variables were selected for the regression model according to literatures: ownership concentration (Cen), management shareholding (Mstock), ownership (SOE), chief executive officer (CEO), duality (Duality), top manager compensation (Rev), and return on assets (ROA). Each model contains time (Year) and industry (Industry) fixed effects. All variables are defined in Table 1.

3.3. Empirical Model. The effects of FC on RD were estimated by the following regression model:

$$
\begin{aligned}
\mathrm{RD}_{i, t}= & a_{0}+b_{1} \mathrm{FC}_{i, t}+b_{2} \mathrm{FC}_{i, t}^{2} \\
& +\sum \beta \text { controls }_{i, t}+\text { year }_{t}+\text { industry }_{j}+\varepsilon_{i, t} .
\end{aligned}
$$

The moderating effects of TMN location were assessed by the following hierarchical regression model:

$$
\begin{aligned}
\mathrm{RD}_{i, t}= & a_{0}+b_{1} \mathrm{FC}_{i, t}+b_{2} \mathrm{FC}_{i, t}^{2}+b_{3} \text { Stru }_{i, t} \\
& +b_{4} \operatorname{Stru}_{i, t} \times \mathrm{FC}_{i, t} \\
& +b_{5} \mathrm{Stru}_{i, t}+\mathrm{FC}_{i, t}^{2}+\sum \beta \text { controls }_{i, t}
\end{aligned}
$$

where $\mathrm{RD}_{i, t}$ is the $\mathrm{R} \& \mathrm{D}$ investment of enterprise $i$ in year $t$, which is measured in two ways: the main tests adopt the first proxy, i.e., the ratio of $\mathrm{R} \& \mathrm{D}$ expenditure to total assets; the robustness tests adopt the second proxy, i.e., the ratio of $\mathrm{R} \& \mathrm{D}$ expenditure to annual income; $\mathrm{FC}_{i, t}$ represent the financing constraints of enterprise $i$ in year $t ; \mathrm{FC}_{i, t}^{2}$ represent the squared financing constraints of enterprise $i$ in year $t$; $\mathrm{SH}_{i, t}$ is the $\mathrm{SH}$ of the TMN of enterprise $i$ in year $t$; controls $_{i, t}$ 
TABLE 1: Main variables and definitions.

\begin{tabular}{|c|c|c|c|}
\hline Type & Name & Symbol & Description \\
\hline \multirow{3}{*}{$\begin{array}{l}\text { Dependent } \\
\text { variable } \\
\text { Independent } \\
\text { variables }\end{array}$} & $\begin{array}{l}\mathrm{R} \& \mathrm{D} \text { investment } \\
\text { intensity }\end{array}$ & $\mathrm{RD}$ & $\operatorname{Ln}(\mathrm{R} \& \mathrm{D}$ investment/total assets $)$ \\
\hline & Financing constraints & FC & Built by several variables according to $\mathrm{Gu}$ and Zhai [33] \\
\hline & $\begin{array}{l}\text { Squared financing } \\
\text { constraints }\end{array}$ & $\mathrm{FC}^{2}$ & Square of normalized financing constraints \\
\hline \multirow{13}{*}{$\begin{array}{l}\text { Moderator variable } \\
\text { Control variables }\end{array}$} & SH index & $\mathrm{SH}$ & Location of SHs in TMN \\
\hline & Financial leverage & Lev & Total liabilities/total assets \\
\hline & Profitability & ROA & Net profit/mean balance of assets \\
\hline & $\begin{array}{l}\text { Ownership } \\
\text { concentration }\end{array}$ & Cen & Shareholding ratio of top-10 shareholders \\
\hline & $\begin{array}{l}\text { Top manager } \\
\text { compensation }\end{array}$ & Rev & $\operatorname{Ln}($ top manager compensation) \\
\hline & CEO duality & Dual & Integration of chairman and general manager, 1 ; otherwise, 0 \\
\hline & $\begin{array}{l}\text { Management } \\
\text { shareholding }\end{array}$ & Mstock & Level of management share ownership \\
\hline & Cash holding & Cash & Balance of cash and cash equivalents/total assets \\
\hline & Ownership & SOE & State-owned, 1 ; otherwise, 0 \\
\hline & Listed year & Age & $\operatorname{Ln}($ the year of study - the year of listed +1$)$ \\
\hline & Size & Size & Ln(total assets) \\
\hline & Time & Year & Virtual variable with 2013 as the base year \\
\hline & Industry & Industry & $\begin{array}{l}\text { Virtual variable set according to the Guidelines for the Industry Classification of } \\
\text { Listed Companies of CSRC, } 2012\end{array}$ \\
\hline
\end{tabular}

represent the control variables of enterprise $i$ in year $t ; a_{0}$ is the constant term; $b_{1}$ and $b_{2}$ are the coefficient and quadratic term of financing constraints, respectively; $b_{4}$ is the coefficient of SH index; $b_{4}$ and $b_{5}$ are the coefficient of the interaction between TMN location and financing constraints and that of the interaction between TMN location and squared financing constraints, respectively, which represent the moderating effect of TMN hole on FC; $\varepsilon_{i, t}$ is the coefficient of the control variable; and $\beta$ is a random disturbance term. In both models, time fixed effects and industry fixed effects are controlled.

\section{Result Analysis}

4.1. Descriptive Statistics and Correlations. According to the descriptive statistics of variables (Table 2), the maximum, minimum, and mean of $\mathrm{RD}$ were $1.067,0$, and 0.52 , respectively, with a standard deviation of 0.135 . Hence, different enterprises vary significantly in RD. The maximum, minimum, and mean of SH were 1.62, 0.077, and 0.415, respectively, with a standard deviation of 0.216 . This means that the TMN location differs from enterprise to enterprise. The maximum, minimum, and mean of FC were 0.994, 0.229 , and 0.445 , respectively, with a standard deviation of 0.282 , indicating the huge variation of FC level among enterprises.

The correlation test results (Table 3 ) show that corporate $\mathrm{RD}$ has a significant positive correlation with FC and an insignificant negative correlation with TMN location. The correlation coefficients of most variables were below 0.5 , and the variance inflation factors (VIFs) were all smaller than 5. Therefore, there is no serious multicollinearity between variables.
TABLE 2: Descriptive statistics of variables.

\begin{tabular}{lccccc}
\hline Variable & Obs & Mean & Std. Dev. & Min & Max \\
\hline RD & 5773 & 0.052 & 0.135 & 0 & 1.067 \\
FC & 5773 & 0.508 & 0.167 & 0.229 & 0.994 \\
SH & 5773 & 0.415 & 0.216 & 0.077 & 1.62 \\
Lev & 5773 & 0.445 & 0.282 & 0.007 & 11.51 \\
ROA & 5773 & 0.044 & 0.35 & -11.296 & 22.005 \\
Cash & 5773 & 0.249 & 0.185 & 0.006 & 1.079 \\
Cen & 5773 & 0.581 & 0.153 & 0.222 & 0.951 \\
Dual & 5773 & 0.247 & 0.431 & 0 & 1 \\
Age & 5773 & 2.111 & 0.877 & 0 & 3.296 \\
Size & 5773 & 22.002 & 1.201 & 14 & 28.243 \\
SOE & 5773 & 0.473 & 0.499 & 0 & 1 \\
Mstock & 5773 & 0.042 & 0.109 & 0 & 0.791 \\
Rev & 5773 & 15.292 & 0.843 & 0 & 18.771 \\
\hline
\end{tabular}

\subsection{Empirical Results}

4.2.1. Basic Regression Results. Table 4 presents the regression results of $\mathrm{FC}$ on $\mathrm{RD}$. Column 1 reports the regression results of $\mathrm{RD}$ on $\mathrm{FC}$ and $\mathrm{FC}^{2}$ with control variables. The coefficient estimate of FC was positive and significant (coefficient: $0.319 ; T$-value: 3.900 at $1 \%$ level of significance), and that of $\mathrm{FC}^{2}$ was negative and significant (coefficient: -0.489 ; $T$-value: -2.200 at $1 \%$ level of significance), revealing an inverted $U$-shaped relationship between FC and RD. Hypothesis 1 is therefore verified. Financing constraints have a significant impact on corporate R\&D input. Moderate financing constraints encourage managers to invest the limited resources in projects with high innovation efficiency. However, excessive financing constraints will deprive an enterprise with available resources and increase innovation risk, forcing the 


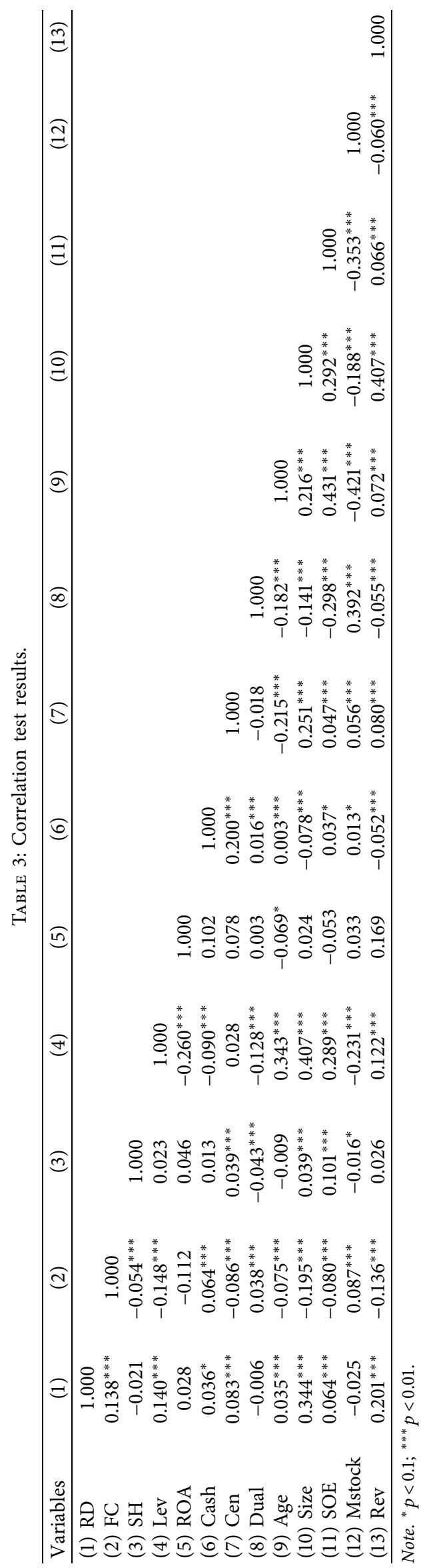


TABLE 4: Results of regression analysis.

\begin{tabular}{|c|c|c|c|}
\hline & $\begin{array}{l}\text { Model } 1 \\
\text { RD }\end{array}$ & $\begin{array}{c}\text { Model } 2 \\
\text { RD }\end{array}$ & $\begin{array}{c}\text { Model } 3 \\
\text { RD }\end{array}$ \\
\hline FC & $\begin{array}{c}0.319^{* * *} \\
(0.031)\end{array}$ & $\begin{array}{c}0.319^{* * *} \\
(0.031)\end{array}$ & $\begin{array}{c}0.317^{* * *} \\
(0.031)\end{array}$ \\
\hline $\mathrm{FC}^{2}$ & $\begin{array}{c}-0.489^{* * *} \\
(0.080)\end{array}$ & $\begin{array}{c}-0.480^{* * *} \\
(0.079)\end{array}$ & $\begin{array}{c}-0.485^{* * *} \\
(0.080)\end{array}$ \\
\hline $\mathrm{SH}$ & & $\begin{array}{c}0.004 \\
(0.010)\end{array}$ & $\begin{array}{l}0.022^{*} \\
(0.013)\end{array}$ \\
\hline $\mathrm{FC} \times \mathrm{SH}$ & & $\begin{array}{c}0.026^{* *} \\
(0.012)\end{array}$ & $\begin{array}{l}0.046^{* *} \\
(0.019)\end{array}$ \\
\hline $\mathrm{FC}^{2} \times \mathrm{SH}$ & & & $\begin{array}{c}-0.146^{* *} \\
(0.070)\end{array}$ \\
\hline Lev & $\begin{array}{l}0.037^{*} \\
(0.020)\end{array}$ & $\begin{array}{l}0.038^{*} \\
(0.020)\end{array}$ & $\begin{array}{l}0.037^{*} \\
(0.020)\end{array}$ \\
\hline $\mathrm{ROA}$ & $\begin{array}{c}0.043 \\
(0.030)\end{array}$ & $\begin{array}{c}0.042 \\
(0.030)\end{array}$ & $\begin{array}{c}0.040 \\
(0.029)\end{array}$ \\
\hline Cash & $\begin{array}{c}0.023 \\
(0.020)\end{array}$ & $\begin{array}{c}0.022 \\
(0.020)\end{array}$ & $\begin{array}{c}0.022 \\
(0.020)\end{array}$ \\
\hline Cen & $\begin{array}{c}0.085 \\
(0.058)\end{array}$ & $\begin{array}{c}0.084 \\
(0.058)\end{array}$ & $\begin{array}{c}0.082 \\
(0.058)\end{array}$ \\
\hline Dual & $\begin{array}{l}-0.010 \\
(0.009)\end{array}$ & $\begin{array}{l}-0.010 \\
(0.009)\end{array}$ & $\begin{array}{l}-0.010 \\
(0.009)\end{array}$ \\
\hline Age & $\begin{array}{c}0.014 \\
(0.029)\end{array}$ & $\begin{array}{c}0.014 \\
(0.029)\end{array}$ & \\
\hline Size & $\begin{array}{l}0.019^{* *} \\
(0.009)\end{array}$ & $\begin{array}{l}0.019^{* *} \\
(0.009)\end{array}$ & $\begin{array}{l}0.019^{* *} \\
(0.009)\end{array}$ \\
\hline SOE & $\begin{array}{l}0.066^{* *} \\
(0.033)\end{array}$ & $\begin{array}{l}0.066^{* *} \\
(0.033)\end{array}$ & $\begin{array}{l}0.067^{* *} \\
(0.033)\end{array}$ \\
\hline Mstock & $\begin{array}{l}-0.040 \\
(0.050)\end{array}$ & $\begin{array}{l}-0.042 \\
(0.050)\end{array}$ & $\begin{array}{l}-0.042 \\
(0.049)\end{array}$ \\
\hline Rev & $\begin{array}{c}0.001 \\
(0.003)\end{array}$ & $\begin{array}{c}0.001 \\
(0.003)\end{array}$ & $\begin{array}{c}0.001 \\
(0.003)\end{array}$ \\
\hline _cons & $\begin{array}{c}-0.699^{* * *} \\
(0.225)\end{array}$ & $\begin{array}{c}-0.695^{* * *} \\
(0.225)\end{array}$ & $\begin{array}{c}-0.703^{* * *} \\
(0.225)\end{array}$ \\
\hline Obs. & 5,773 & 5,773 & 5,773 \\
\hline R-squared & 0.179 & 0.180 & 0.182 \\
\hline
\end{tabular}

Note. Standard errors are in parenthesis; ${ }^{*} p<0.1 ;{ }^{* *} p<0.05 ;{ }^{* * *} p<0.01$.

enterprise to scale down innovation investment. The results cannot determine the optimal value of $\mathrm{FC}$, which is a limitation of this study.

4.2.2. Moderating Effect of TMN Location. In Table 4, columns 2 and 3 report the moderating effect of TMN location. The coefficient of TMN location was 0.022 , and the $T$-value was 1.940 , which is significant at $10 \%$ level. Therefore, the corporate innovation investment increases as the TMN location gets nearer to the $\mathrm{SH}$.

Based on Model 1, an interaction term FC $\times \mathrm{SH}$ between $\mathrm{FC}$ and $\mathrm{SH}$ was added for regression analysis (Model 2). The results show that the coefficient of $\mathrm{FC} \times \mathrm{SH}$ was 0.064 ( $T$ value $=2.800$ at $5 \%$ level of significance), indicating that TMN location enhances the promoting effect of appropriate FC on RD.

Based on Model 2, an interaction term $\mathrm{FC}^{2} \times \mathrm{SH}$ between squared $\mathrm{FC}$ and $\mathrm{SH}$ was added for regression analysis (Model $3)$. The results show that the coefficient of $\mathrm{FC}^{2} \times \mathrm{SH}$ was 0.146 ( $T$-value $=2.600$ at $5 \%$ level of significance), indicting that TMN location enhances the inhibiting effect of excessive $\mathrm{FC}$ on RD.
Overall, TMN location significantly strengthens the inverted U-shaped relationship between FC and RD, which supports Hypothesis 2.

\subsection{Robustness Tests}

4.3.1. Robustness Test on TMN Location. In this robustness test, the TMN location was measured by the total number of holes in corporate management structure, i.e., the total number of SHs of all top managers of the enterprise.

As shown in Table 5, the results of the robustness test were basically consistent with the results of the basic regression: there is a clear inverted U-shaped relationship between FC and corporate innovation input; the coefficient of TMN location was 0.005 , which is not significant. Hence, corporate R\&D input increases as the TMN location gets closer to the $\mathrm{SH}$, but this correlation is not significant.

The coefficient of the cross term between FC and TMN location was 0.066 , and the $T$-value was 2.800 , which is significant at $5 \%$ level. The coefficient of the cross term between squared FC and TMN location was -0.188 , and the $T$-value was 2.600 , which is significant at $5 \%$ level. Thus, the TMN location significantly strengthens the inverted $\mathrm{U}$-shaped relationship FC and $\mathrm{RD}$, and the results of basic regression were basically robust.

4.3.2. Robustness Test on FC. The financing constraints were recalculated. Based on the first ranking, the contradictory samples in the group were deleted by cash dividend payout ratio. Then, a new FC index was obtained.

As shown in Table 5, the coefficient of FC was 0.246 , and the $T$-value was 3.900 , which is significant at the $1 \%$ level. The coefficient of squared FC was -0.326 , and the $T$-value was -2.200 , which is significant at the $1 \%$ level. Hence, the relationship between FC and RD still takes the shape of an inverted U; TMN location still greatly enhances the inverted $\mathrm{U}$-shaped relationship between FC and RD, which further verifies the results of main regression.

4.3.3. Endogeneity Test. There is a reciprocal causality between $\mathrm{FC}$ and $\mathrm{RD}$. Therefore, the main explanatory variables, $\mathrm{FC}$ and $\mathrm{FC}^{2}$, were regressed with a lag of one period. According to the results in Table 6, FC still has a significant non-linear relationship with $\mathrm{RD}$, which is shaped like an inverted U; TMN location still moderates the relationship between FC and RD.

\section{Additional Analysis on the Influence of Ownership}

In China, enterprises are either owned by the state or not. SOEs and non-SOEs differ significantly in terms of FC and $\mathrm{RD}$ [37]. The long agency chain, coupled with the defects of the tenure system, makes SOE management concerned with their political future and drives them to pursue short-term interests in office. Hence, TMN location has little impact on FC and RD of SOEs. In non-SOEs, the top managers are not highly politically motivated. Due to the credit discrimination 
TABLE 5: Results of robustness test.

\begin{tabular}{|c|c|c|c|c|c|c|}
\hline & \multicolumn{3}{|c|}{ Mean replaced with the sum of SHs } & \multicolumn{3}{|c|}{ Recalculated FC } \\
\hline & $\begin{array}{c}\text { Model } 1 \\
\text { RD }\end{array}$ & $\begin{array}{c}\text { Model } 2 \\
\text { RD }\end{array}$ & $\begin{array}{c}\text { Model } 3 \\
\text { RD }\end{array}$ & $\begin{array}{c}\text { Model } 1 \\
\text { RD }\end{array}$ & $\begin{array}{c}\text { Model } 2 \\
\text { RD }\end{array}$ & $\begin{array}{c}\text { Model } 3 \\
\text { RD }\end{array}$ \\
\hline FC & $\begin{array}{c}0.319^{* * *} \\
(0.031)\end{array}$ & $\begin{array}{c}0.317^{* * *} \\
(0.031)\end{array}$ & $\begin{array}{c}0.312^{* * *} \\
(0.030)\end{array}$ & $\begin{array}{c}0.246^{* * *} \\
(0.019)\end{array}$ & $\begin{array}{c}0.246^{* * *} \\
(0.019)\end{array}$ & $\begin{array}{c}0.246^{* * *} \\
(0.019)\end{array}$ \\
\hline $\mathrm{FC}^{2}$ & $\begin{array}{c}-0.489^{* * *} \\
(0.080)\end{array}$ & $\begin{array}{c}-0.469^{* * *} \\
(0.079)\end{array}$ & $\begin{array}{c}-0.468^{* * *} \\
(0.078)\end{array}$ & $\begin{array}{c}-0.322^{* * *} \\
(0.067)\end{array}$ & $\begin{array}{c}-0.317^{* * *} \\
(0.067)\end{array}$ & $\begin{array}{c}-0.326^{* * *} \\
(0.067)\end{array}$ \\
\hline $\mathrm{SH}$ & & $\begin{array}{l}-0.001 \\
(0.004)\end{array}$ & $\begin{array}{c}0.005 \\
(0.006)\end{array}$ & & $\begin{array}{c}0.002 \\
(0.009)\end{array}$ & $\begin{array}{c}0.018 \\
(0.013)\end{array}$ \\
\hline $\mathrm{FC} \times \mathrm{SH}$ & & $\begin{array}{c}0.044^{* *} \\
(0.022)\end{array}$ & $\begin{array}{c}0.066^{* *} \\
(0.028)\end{array}$ & & $\begin{array}{c}0.011 \\
(0.011)\end{array}$ & $\begin{array}{l}0.022^{*} \\
(0.012)\end{array}$ \\
\hline $\mathrm{FC}^{2} \times \mathrm{SH}$ & & & $\begin{array}{c}-0.188^{*} \\
(0.097)\end{array}$ & & & $\begin{array}{c}-0.084^{*} \\
(0.047)\end{array}$ \\
\hline Lev & $\begin{array}{l}0.037^{*} \\
(0.020)\end{array}$ & $\begin{array}{l}0.038^{*} \\
(0.020)\end{array}$ & $\begin{array}{l}0.037^{*} \\
(0.020)\end{array}$ & $\begin{array}{c}0.049^{* * *} \\
(0.012)\end{array}$ & $\begin{array}{c}0.049^{* * *} \\
(0.012)\end{array}$ & $\begin{array}{c}0.048^{* * *} \\
(0.012)\end{array}$ \\
\hline ROA & $\begin{array}{c}0.043 \\
(0.030)\end{array}$ & $\begin{array}{c}0.040 \\
(0.029)\end{array}$ & $\begin{array}{c}0.037 \\
(0.029)\end{array}$ & $\begin{array}{c}0.153^{* * *} \\
(0.045)\end{array}$ & $\begin{array}{c}0.153^{* * *} \\
(0.045)\end{array}$ & $\begin{array}{c}0.152^{* * *} \\
(0.046)\end{array}$ \\
\hline Cash & $\begin{array}{c}0.023 \\
(0.020)\end{array}$ & $\begin{array}{c}0.022 \\
(0.020)\end{array}$ & $\begin{array}{c}0.021 \\
(0.020)\end{array}$ & $\begin{array}{c}0.042^{* * *} \\
(0.014)\end{array}$ & $\begin{array}{c}0.042^{* * *} \\
(0.014)\end{array}$ & $\begin{array}{c}0.041^{* * *} \\
(0.014)\end{array}$ \\
\hline Cen & $\begin{array}{c}0.085 \\
(0.058)\end{array}$ & $\begin{array}{c}0.086 \\
(0.058)\end{array}$ & $\begin{array}{c}0.085 \\
(0.058)\end{array}$ & $\begin{array}{c}0.025 \\
(0.018)\end{array}$ & $\begin{array}{c}0.025 \\
(0.018)\end{array}$ & $\begin{array}{c}0.026 \\
(0.018)\end{array}$ \\
\hline Dual & $\begin{array}{l}-0.010 \\
(0.009)\end{array}$ & $\begin{array}{l}-0.011 \\
(0.009)\end{array}$ & $\begin{array}{l}-0.010 \\
(0.009)\end{array}$ & $\begin{array}{c}0.006 \\
(0.006)\end{array}$ & $\begin{array}{c}0.006 \\
(0.006)\end{array}$ & $\begin{array}{c}0.006 \\
(0.006)\end{array}$ \\
\hline Age & $\begin{array}{c}0.014 \\
(0.029)\end{array}$ & $\begin{array}{c}0.016 \\
(0.029)\end{array}$ & & $\begin{array}{c}0.001 \\
(0.005)\end{array}$ & $\begin{array}{c}0.001 \\
(0.005)\end{array}$ & \\
\hline Size & $\begin{array}{l}0.019^{* *} \\
(0.009)\end{array}$ & $\begin{array}{l}0.019^{* *} \\
(0.009)\end{array}$ & $\begin{array}{c}0.019^{* *} \\
(0.009)\end{array}$ & $\begin{array}{c}0.044^{* * *} \\
(0.004)\end{array}$ & $\begin{array}{c}0.044^{* * *} \\
(0.004)\end{array}$ & $\begin{array}{c}0.044^{* * *} \\
(0.004)\end{array}$ \\
\hline SOE & $\begin{array}{c}0.066^{* *} \\
(0.033)\end{array}$ & $\begin{array}{l}0.067^{* *} \\
(0.032)\end{array}$ & $\begin{array}{c}0.068^{* *} \\
(0.033)\end{array}$ & $\begin{array}{c}0.001 \\
(0.006)\end{array}$ & $\begin{array}{c}0.001 \\
(0.006)\end{array}$ & $\begin{array}{c}0.001 \\
(0.006)\end{array}$ \\
\hline Mstock & $\begin{array}{l}-0.040 \\
(0.050)\end{array}$ & $\begin{array}{l}-0.045 \\
(0.049)\end{array}$ & $\begin{array}{l}-0.046 \\
(0.049)\end{array}$ & $\begin{array}{c}0.007 \\
(0.019)\end{array}$ & $\begin{array}{c}0.006 \\
(0.019)\end{array}$ & $\begin{array}{c}0.006 \\
(0.019)\end{array}$ \\
\hline Rev & $\begin{array}{c}0.001 \\
(0.003)\end{array}$ & $\begin{array}{c}0.002 \\
(0.003)\end{array}$ & $\begin{array}{c}0.002 \\
(0.003)\end{array}$ & $\begin{array}{c}0.011^{* * * *} \\
(0.003)\end{array}$ & $\begin{array}{c}0.011^{* * * *} \\
(0.003)\end{array}$ & $\begin{array}{c}0.011^{* * *} \\
(0.003)\end{array}$ \\
\hline _cons & $\begin{array}{c}-0.699^{* * *} \\
(0.225)\end{array}$ & $\begin{array}{c}-0.698^{* * *} \\
(0.227)\end{array}$ & $\begin{array}{c}-0.695^{* * *} \\
(0.228)\end{array}$ & $\begin{array}{c}-1.281^{* * *} \\
(0.099)\end{array}$ & $\begin{array}{c}-1.285^{* * *} \\
(0.099)\end{array}$ & $\begin{array}{c}-1.296^{* * *} \\
(0.100)\end{array}$ \\
\hline Obs. & 5773 & 5773 & 5773 & 3528 & 3528 & 3528 \\
\hline R-squared & 0.179 & 0.182 & 0.184 & 0.271 & 0.272 & 0.272 \\
\hline
\end{tabular}

Note. Standard errors are in parenthesis; ${ }^{*} p<0.1 ;{ }^{* *} p<0.05 ;{ }^{* * *} p<0.01$.

TABLE 6: Results of endogeneity test.

\begin{tabular}{|c|c|c|c|}
\hline & $\begin{array}{c}\text { Model } 1 \\
\text { RD }\end{array}$ & $\begin{array}{c}\text { Model } 2 \\
\text { RD }\end{array}$ & $\begin{array}{c}\text { Model } 3 \\
\text { RD }\end{array}$ \\
\hline L.FC & $\begin{array}{c}0.096^{* * *} \\
(0.029)\end{array}$ & $\begin{array}{c}0.097^{* * *} \\
(0.029)\end{array}$ & $\begin{array}{c}0.095^{* * *} \\
(0.029)\end{array}$ \\
\hline L.FC ${ }^{2}$ & $\begin{array}{c}-0.147^{*} \\
(0.078)\end{array}$ & $\begin{array}{c}-0.147^{*} \\
(0.078)\end{array}$ & $\begin{array}{c}-0.142^{*} \\
(0.078)\end{array}$ \\
\hline $\mathrm{SH}$ & & $\begin{array}{c}0.009 \\
(0.014)\end{array}$ & $\begin{array}{l}0.037^{*} \\
(0.019)\end{array}$ \\
\hline $\mathrm{FC} \times \mathrm{SH}$ & & $\begin{array}{c}0.010 \\
(0.014)\end{array}$ & $\begin{array}{l}0.041^{*} \\
(0.022)\end{array}$ \\
\hline $\mathrm{FC}^{2} \times \mathrm{SH}$ & & & $\begin{array}{c}-0.212^{* *} \\
(0.087)\end{array}$ \\
\hline Lev & $\begin{array}{c}0.036 \\
(0.024)\end{array}$ & $\begin{array}{c}0.037 \\
(0.024)\end{array}$ & $\begin{array}{c}0.036 \\
(0.024)\end{array}$ \\
\hline ROA & $\begin{array}{c}0.036 \\
(0.031)\end{array}$ & $\begin{array}{c}0.036 \\
(0.031)\end{array}$ & $\begin{array}{c}0.033 \\
(0.031)\end{array}$ \\
\hline Cash & $\begin{array}{c}0.025 \\
(0.031)\end{array}$ & $\begin{array}{c}0.024 \\
(0.031)\end{array}$ & $\begin{array}{c}0.024 \\
(0.031)\end{array}$ \\
\hline Cen & 0.101 & 0.101 & 0.096 \\
\hline
\end{tabular}


TABle 6: Continued.

\begin{tabular}{|c|c|c|c|}
\hline & $\begin{array}{c}\text { Model } 1 \\
\text { RD }\end{array}$ & $\begin{array}{c}\text { Model } 2 \\
\text { RD }\end{array}$ & $\begin{array}{c}\text { Model } 3 \\
\text { RD }\end{array}$ \\
\hline & $(0.082)$ & $(0.081)$ & $(0.081)$ \\
\hline Dual & $\begin{array}{c}0.001 \\
(0.011)\end{array}$ & $\begin{array}{c}0.001 \\
(0.011)\end{array}$ & $\begin{array}{c}0.002 \\
(0.012)\end{array}$ \\
\hline Age & $\begin{array}{l}-0.026 \\
(0.034)\end{array}$ & $\begin{array}{l}-0.025 \\
(0.034)\end{array}$ & \\
\hline Size & $\begin{array}{c}0.024^{* *} \\
(0.010)\end{array}$ & $\begin{array}{c}0.024^{* *} \\
(0.010)\end{array}$ & $\begin{array}{c}0.024^{* *} \\
(0.010)\end{array}$ \\
\hline SOE & $\begin{array}{c}0.063 \\
(0.042)\end{array}$ & $\begin{array}{c}0.063 \\
(0.042)\end{array}$ & $\begin{array}{c}0.066 \\
(0.043)\end{array}$ \\
\hline Mstock & $\begin{array}{l}-0.064 \\
(0.052)\end{array}$ & $\begin{array}{l}-0.064 \\
(0.052)\end{array}$ & $\begin{array}{l}-0.062 \\
(0.052)\end{array}$ \\
\hline Rev & $\begin{array}{c}0.002 \\
(0.006)\end{array}$ & $\begin{array}{c}0.002 \\
(0.006)\end{array}$ & $\begin{array}{c}0.002 \\
(0.006)\end{array}$ \\
\hline _cons & $\begin{array}{c}-0.666^{* *} \\
(0.283)\end{array}$ & $\begin{array}{c}-0.661^{* *} \\
(0.283)\end{array}$ & $\begin{array}{c}-0.673^{* *} \\
(0.283)\end{array}$ \\
\hline Obs. & 4366 & 4366 & 4366 \\
\hline $\mathrm{R}$-squared & 0.084 & 0.084 & 0.088 \\
\hline
\end{tabular}

Note. Standard errors are in parenthesis; ${ }^{*} p<0.1 ;{ }^{* *} p<0.05 ;{ }^{* * *} p<0.01$.

TABLE 7: Results of subsample analysis on SOEs and non-SOEs.

\begin{tabular}{|c|c|c|c|c|c|c|}
\hline & \multicolumn{3}{|c|}{ SOEs } & \multicolumn{3}{|c|}{ Non-SOEs } \\
\hline & $\begin{array}{c}\text { Model } 1 \\
\text { RD }\end{array}$ & $\begin{array}{c}\text { Model } 2 \\
\text { RD }\end{array}$ & $\begin{array}{c}\text { Model } 3 \\
\text { RD }\end{array}$ & $\begin{array}{c}\text { Model } 1 \\
\text { RD }\end{array}$ & $\begin{array}{c}\text { Model } 2 \\
\text { RD }\end{array}$ & $\begin{array}{c}\text { Model } 3 \\
\text { RD }\end{array}$ \\
\hline FC & $\begin{array}{c}0.397^{* * *} \\
(0.052)\end{array}$ & $\begin{array}{c}0.394^{* * *} \\
(0.051)\end{array}$ & $\begin{array}{c}0.390^{* * *} \\
(0.050)\end{array}$ & $\begin{array}{c}0.252^{* * *} \\
(0.036)\end{array}$ & $\begin{array}{c}0.255^{* * *} \\
(0.036)\end{array}$ & $\begin{array}{c}0.257^{* * *} \\
(0.036)\end{array}$ \\
\hline $\mathrm{FC}^{2}$ & $\begin{array}{c}-0.551^{* * *} \\
(0.147)\end{array}$ & $\begin{array}{c}-0.533^{* * *} \\
(0.147)\end{array}$ & $\begin{array}{c}-0.530^{* * *} \\
(0.146)\end{array}$ & $\begin{array}{c}-0.377^{* * *} \\
(0.089)\end{array}$ & $\begin{array}{c}-0.378^{* * *} \\
(0.089)\end{array}$ & $\begin{array}{c}-0.395^{* * *} \\
(0.090)\end{array}$ \\
\hline $\mathrm{SH}$ & & $\begin{array}{l}-0.001 \\
(0.018)\end{array}$ & $\begin{array}{c}0.011 \\
(0.021)\end{array}$ & & $\begin{array}{c}0.012 \\
(0.012)\end{array}$ & $\begin{array}{l}0.031^{* *} \\
(0.015)\end{array}$ \\
\hline $\mathrm{FC} \times \mathrm{SH}$ & & $\begin{array}{c}0.026 \\
(0.023)\end{array}$ & $\begin{array}{c}0.035 \\
(0.028)\end{array}$ & & $\begin{array}{c}0.014 \\
(0.013)\end{array}$ & $\begin{array}{c}0.039^{* *} \\
(0.019)\end{array}$ \\
\hline $\mathrm{FC}^{2} \times \mathrm{SH}$ & & & $\begin{array}{l}-0.108 \\
(0.123)\end{array}$ & & & $\begin{array}{c}-0.143^{* * *} \\
(0.055)\end{array}$ \\
\hline Lev & $\begin{array}{l}0.088^{* *} \\
(0.040)\end{array}$ & $\begin{array}{l}0.089^{* *} \\
(0.040)\end{array}$ & $\begin{array}{l}0.088^{* *} \\
(0.040)\end{array}$ & $\begin{array}{c}0.015 \\
(0.022)\end{array}$ & $\begin{array}{c}0.015 \\
(0.022)\end{array}$ & $\begin{array}{c}0.016 \\
(0.022)\end{array}$ \\
\hline ROA & $\begin{array}{c}0.099^{* *} \\
(0.041)\end{array}$ & $\begin{array}{c}0.100^{* *} \\
(0.041)\end{array}$ & $\begin{array}{c}0.098^{* *} \\
(0.041)\end{array}$ & $\begin{array}{c}0.021 \\
(0.038)\end{array}$ & $\begin{array}{c}0.021 \\
(0.039)\end{array}$ & $\begin{array}{c}0.019 \\
(0.039)\end{array}$ \\
\hline Cash & $\begin{array}{c}0.035 \\
(0.028)\end{array}$ & $\begin{array}{c}0.032 \\
(0.028)\end{array}$ & $\begin{array}{c}0.034 \\
(0.028)\end{array}$ & $\begin{array}{c}0.016 \\
(0.029)\end{array}$ & $\begin{array}{c}0.016 \\
(0.029)\end{array}$ & $\begin{array}{c}0.016 \\
(0.029)\end{array}$ \\
\hline Cen & $\begin{array}{c}0.111 \\
(0.097)\end{array}$ & $\begin{array}{c}0.108 \\
(0.098)\end{array}$ & $\begin{array}{c}0.105 \\
(0.097)\end{array}$ & $\begin{array}{c}0.046 \\
(0.075)\end{array}$ & $\begin{array}{c}0.048 \\
(0.075)\end{array}$ & $\begin{array}{c}0.048 \\
(0.075)\end{array}$ \\
\hline Dual & $\begin{array}{r}-0.000 \\
(0.019)\end{array}$ & $\begin{array}{l}-0.000 \\
(0.019)\end{array}$ & $\begin{array}{l}-0.000 \\
(0.019)\end{array}$ & $\begin{array}{c}-0.016^{*} \\
(0.010)\end{array}$ & $\begin{array}{c}-0.016^{*} \\
(0.009)\end{array}$ & $\begin{array}{l}-0.015 \\
(0.009)\end{array}$ \\
\hline Age & $\begin{array}{l}0.113^{*} \\
(0.068)\end{array}$ & $\begin{array}{l}0.112^{*} \\
(0.068)\end{array}$ & $\begin{array}{c}0.109 \\
(0.067)\end{array}$ & $\begin{array}{l}-0.040 \\
(0.036)\end{array}$ & $\begin{array}{l}-0.039 \\
(0.036)\end{array}$ & $\begin{array}{l}-0.038 \\
(0.036)\end{array}$ \\
\hline Size & $\begin{array}{c}0.025 \\
(0.022)\end{array}$ & $\begin{array}{c}0.024 \\
(0.022)\end{array}$ & $\begin{array}{c}0.025 \\
(0.022)\end{array}$ & $\begin{array}{l}0.014^{*} \\
(0.009)\end{array}$ & $\begin{array}{c}0.014 \\
(0.009)\end{array}$ & $\begin{array}{l}0.014^{*} \\
(0.008)\end{array}$ \\
\hline SOE & $\begin{array}{c}0.061 \\
(0.253)\end{array}$ & $\begin{array}{c}0.053 \\
(0.250)\end{array}$ & $\begin{array}{c}0.049 \\
(0.247)\end{array}$ & $\begin{array}{l}-0.052 \\
(0.048)\end{array}$ & $\begin{array}{l}-0.054 \\
(0.048)\end{array}$ & $\begin{array}{l}-0.054 \\
(0.048)\end{array}$ \\
\hline Mstock & $\begin{array}{c}0.000 \\
(0.003)\end{array}$ & $\begin{array}{c}0.000 \\
(0.003)\end{array}$ & $\begin{array}{c}0.000 \\
(0.003)\end{array}$ & $\begin{array}{c}0.013 \\
(0.009)\end{array}$ & $\begin{array}{c}0.013 \\
(0.009)\end{array}$ & $\begin{array}{c}0.013 \\
(0.009)\end{array}$ \\
\hline Rev & $\begin{array}{c}-1.106^{* *} \\
(0.539)\end{array}$ & $\begin{array}{c}-1.085^{* *} \\
(0.534)\end{array}$ & $\begin{array}{c}-1.091^{* *} \\
(0.535)\end{array}$ & $\begin{array}{c}-0.564^{* *} \\
(0.281)\end{array}$ & $\begin{array}{c}-0.497^{*} \\
(0.265)\end{array}$ & $\begin{array}{c}-0.495^{*} \\
(0.264)\end{array}$ \\
\hline _cons & 2534 & 2534 & 2534 & 3239 & 3239 & 3239 \\
\hline $\mathrm{R}$-squared & 0.204 & 0.205 & 0.205 & 0.164 & 0.165 & 0.167 \\
\hline
\end{tabular}

Note. Standard errors are in parenthesis; ${ }^{*} p<0.1 ;{ }^{* *} p<0.05 ;{ }^{* * *} p<0.01$. 
of relevant policies, non-SOEs face much stronger FC than SOEs [38, 39] and might be affected greatly by TMN location. Therefore, TMN location adjustment is expected to affect non-SOEs more significantly than SOEs.

Table 7 reports the results of subsample analysis on SOEs and non-SOEs. The results show a significant inverted U-shaped relationship between FC and RD in both SOEs and non-SOEs. For non-SOEs, the coefficient of $\mathrm{FC} \times \mathrm{SH}$ was significantly positive, indicating that the TMN location enhances the promoting effect of appropriate financing constraints on $\mathrm{R} \& \mathrm{D}$ input. The coefficient of $\mathrm{FC}^{2} \times \mathrm{SH}$ was significantly negative, implying that the moderating effect of TMN location is more significant in non-SOEs than in SOEs.

\section{Conclusions}

This paper empirically studies the data of A-share listed enterprises in Shanghai and Shenzhen stock exchanges during 2009-2019 and draws the following conclusions:

(1) There is a significant inverted U-shaped relationship between financing constraints and corporate R\&D investment.

(2) TMN location moderates the inverted U-shaped relationship between financing constraints and corporate R\&D investment.

(3) The promoting effect of TMN location on the relationship between financing constraints and corporate $\mathrm{R} \& \mathrm{D}$ investment varies with the ownership of the enterprise. Compared with SOEs, nonSOEs rely heavily on TMN location to obtain resources, thus alleviating financing constraints. Therefore, the moderating effect of TMN location is more significant in non-SOEs than in SOEs.

Based on the above conclusions, several suggestions were put forward for enterprises and the government:

(1) Every enterprise should grasp its degree of financing constraints accurately and make pertinent control of their innovation activities [40]. If the financing constraints are light, the enterprise should strive to improve the efficiency of $\mathrm{R} \& \mathrm{D}$ investment and enhance the vitality of innovation. If the financing constraints are strong, the managers should balance resource allocation and seek to alleviate the shortage of funds, trying to mitigate the inhibiting effect of financing constraints on corporate R\&D investment. The shareholders and the board must step up risk control of the TMN, set up a reporting system of the top management, regularly inspect the utilization efficiency of network resources, and work to alleviate the agency problem. To prevent the short-sighted behaviors of top managers, more long-term incentives should be provided to motivate corporate innovation.

(2) The government should strengthen the regulation of financial market and guide the healthy development of the TMN. The effect of TMN regulation differs with corporate ownerships. For SOEs, the government should roll out a series of appraisal standards and regulations to promote the SOE reform, reduce the chances for managers to take short-sighted behaviors, alleviate the relevant agency problems, and prompt the top managers to better allocate resources. For non-SOEs, the government should introduce preferential credit policies to end the credit discrimination against non-SOEs and provide policy support for their corporate innovation.

\section{Data Availability}

The data used to support the findings of this study are available from the corresponding author upon request.

\section{Conflicts of Interest}

The author declares that there are no conflicts of interest.

\section{References}

[1] B. Verspagen, "Innovation and economic growth," in The Oxford Handbook of InnovationOxford University Press, Oxford, UK, 2009.

[2] K. Xu, C. Geng, X. Wei, and H. Jiang, "Financing development, financing constraint and R\&D investment of strategic emerging industries in China," Journal of Business Economics and Management, vol. 21, no. 4, pp. 1010-1034, 2020.

[3] J. R. Brown, G. Martinsson, and B. C. Petersen, "Do financing constraints matter for R\&D?" European Economic Review, vol. 56, no. 8, pp. 1512-1529, 2011.

[4] X. Lu, Y. F. Zheng, and J. M. Li, "Research on the influence of financing constraints on enterprise $R \& D$ investment-empirical evidence from China's listed high-tech companies," Accounting Research, vol. 5, pp. 51-58, 2013.

[5] W. Q. Liu, Y. Q. He, and Y. Zheng, "Financial deepening, financing constraint and enterprise's R\&D investment-an analysis from the perspective of industry heterogeneity," Jiangxi Social Sciences, vol. 38, no. 12, pp. 215-224, 2018.

[6] B. Sun, S. Liu, and J. H. Jiang, "Corporate financing constraints and innovation performance: human capital social network perspective," China Management, vol. 4, pp. 179-189, 2019.

[7] S. M. Fazzari, R. G. Hubbard, B. C. Petersen, A. S. Blinder, and J. M. Poterba, "Financing constraints and corporate investment," Brookings Papers on Economic Activity, vol. 1988, no. 1, pp. 141-206, 1988.

[8] A. Canepa and P. Stoneman, "Financial constraints to innovation in the UK and other European Countries: evidence from CIS2 and CIS3," in Proceedings of the CIS User Group Conference, DTI Conference Centre, London, UK, 2003.

[9] T. H. Goodman, How Do Contracts Adapt to an Increase in Free Cash Flow? (Working Paper), University of Pennsylvania, Philadelphia, PA, USA, 2005.

[10] V. Sena, "The determinants of firms' performance: can finance constraints improve technical efficiency?" European Journal of Operational Research, vol. 172, no. 1, pp. 311-325, 2006.

[11] D. Kahneman and A. Tversky, "Prospect theory: an analysis of decision under risk," Econometrica, vol. 47, no. 2, pp. 263-291, 1979.

[12] W. P. Burgers, C. W. L. Hill, and W. C. Kim, "A theory of global strategic alliances: the case of the global auto industry," 
Strategic Management Journal, vol. 14, no. 6, pp. 419-432, 1993.

[13] C. P. Himmelberg and B. C. Petersen, "R\&D and internal finance: a panel study of small firms in high-tech industries," The Review of Economics and Statistics, vol. 76, no. 1, pp. 38-51, 1994.

[14] B. H. Hall and J. Lerner, "The financing of R\&D and innovation," Handbook of the Economics of Innovation, vol. 1, pp. 609-639, 2010.

[15] D. Li, "Financial constraints, R\&D investment, and stock returns," Review of Financial Studies, vol. 24, no. 9, pp. 2974-3007, 2011.

[16] F. Silva and C. Carreira, "Do financial constraints threat the innovation process? Evidence from Portuguese firms," Economics of Innovation and New Technology, vol. 21, no. 8, pp. 701-736, 2012.

[17] E. Yang, G. Ma, and J. Chu, "The impact of financial constraints on firm R\&D investments: empirical evidence from China," International Journal of Technology Management, vol. 65, no. 1, pp. 172-188, 2014.

[18] Q. Gu and S. P. Zhai, "Financial constraints, R\&D investment and funding sources: the perspective of R\&D heterogeneity," Science of Science and Management of $S$ \& $T$, vol. 35, no. 3, pp. 15-22, 2014.

[19] Y. Xia and P. Liu, "The effects of bank competition on firm R\&D investment: an inverted-U relationship," Chinese Management Studies, vol. 15, no. 3, pp. 641-666, 2021.

[20] A. Howell, "“Indigenous" innovation with heterogeneous risk and new firm survival in a transitioning Chinese economy," Research Policy, vol. 44, no. 10, pp. 1866-1876, 2015.

[21] S. C. Myers and N. S. Majluf, "Corporate financing and investment decisions when firms have information that investors do not have," Journal of Financial Economics, vol. 13, no. 2, pp. 187-221, 1984.

[22] M. Gibbert, M. Hoegl, and L. Valikangas, "Introduction to the special issue: financial resource constraints and innovation," Journal of Product Innovation Management, vol. 31, no. 2, pp. 197-201, 2014.

[23] C. Lu and S. Chen, "Reconfiguration of interlocking directors and their organizational functions," Management World, vol. 5, pp. 152-165, 2009.

[24] Y. Chen and D. Xie, "Network location, Independent director governance and investment efficiency," Management World, vol. 7, pp. 113-127, 2011.

[25] G. Zhang and Y. Shi, "Accounting conservatism, executive social networks and firm innovation: evidence from Chinese listed companies," Financial Theory \& Practice, vol. 38, no. 3, pp. 84-90, 2017.

[26] G. Zhuang, Y. Xi, and X. Zhou, "Power, conflict and cooperation: the Impact of personal relationship in Chinese marketing channels," Management Science, vol. 3, pp. 38-47, 2007.

[27] A. Escribano, A. Fosfuri, and J. A. Tribó, "Managing external knowledge flows: the moderating role of absorptive capacity," Research Policy, vol. 38, no. 1, pp. 96-105, 2009.

[28] O. Sorenson and T. E. Stuart, "Syndication networks and the spatial distribution of venture capital investments," American Journal of Sociology, vol. 106, no. 6, pp. 1546-1588, 2001.

[29] E. Porter and S. Stern, "Innovation: location matters," MIT Sloan Management Review, vol. 42, no. 4, pp. 28-36, 2001.

[30] J. R. Kale and H. Shahrur, "Corporate capital structure and the characteristics of suppliers and customers," Journal of Financial Economics, vol. 83, no. 2, pp. 321-365, 2007.
[31] A. Rego, P. Oliveira, and P. Rosado, "Product innovation in resource-poor environments: three research streams," Journal of Product Innovation Management, vol. 31, no. 2, pp. 202210, 2014.

[32] W. $\mathrm{Li}$ and M. Yu, "Ownership structure and enterprise innovation of privatized enterprises," Management World, vol. 4, pp. 112-125, 2015.

[33] Q. Gu and S. Zhai, "Financing constraints, agency costs and firm innovation efficiency: empirical evidence from listed high-tech firms," Economic and Management Research, vol. 5, pp. 73-80, 2012.

[34] R. S. Burt, The Social Structure of Competition, Harvard University Press, Cambridge, MA, USA, 1992.

[35] A. Zaheer and G. G. Bell, "Benefiting from network position: firm capabilities, structural holes, and performance," Strategic Management Journal, vol. 26, no. 9, pp. 809-825, 2005.

[36] R. Yan, X. Hua, and J. Qian, "Research on the Impact of interlocking director network on enterprise innovation investment under the moderating effect of organizational redundancy and property right," Journal of Management, vol. 2, pp. 217-229, 2018.

[37] H. Chen, J. Z. Chen, G. J. Lobo, and Y. Wang, “Association between borrower and lender state ownership and accounting conservatism," Journal of Accounting Research, vol. 48, no. 5, pp. 973-1014, 2010.

[38] J. Wu, "Financing constraints for R\&D in China: the role of state ownership," Applied Economics Letters, vol. 26, no. 14, pp. 1162-1166, 2019.

[39] X. Zhao, Z. Wang, and M. Deng, "Interest rate marketization, financing constraints and R\&D investments: evidence from China," Sustainability, vol. 11, no. 8, pp. 2311-2328, 2019.

[40] X. Yin, B.-1. Hai, and J. Chen, "Financial constraints and R\&D investment: the moderating role of CEO characteristics," Sustainability, vol. 11, no. 15, pp. 4153-4171, 2019. 